\title{
2.2. Finansowanie zadań oświatowych w edukacji włączającej
}

DOI: $10.47050 / 65591838.124-136$

Liliana Zientecka

Realizacja idei edukacji włączającej wysokiej jakości wiąże się z odpowiednimi regulacjami w prawnymi i skutecznym modelem finansowania. Autorka analizuje obecne unormowania finansowe w polskim systemie oświaty, wskazując jednocześnie proponowane kierunki zmian, dzięki którym możliwe będzie skuteczniejsze wsparcie wszystkich uczniów, także tych ze specjalnymi potrzebami edukacyjnymi.

\section{Słowa kluczowe:}

model finansowania zadań oświatowych

finansowe dźwignie edukacji włączającej 


\subsection{Hinancing of educational tasks in inclusive education}

DOI: $10.47050 / 65591838.124-136$

Liliana Zientecka

Implementation of the idea of high-quality inclusive education requires implementation of corresponding regulations in the legal system and effective model of financing. The author analyses current financial regulations in Polish education system and indicates the proposed directions of changes, allowing to provide more effective support for all students, including those with special educational needs.

\section{Keywords:}

model of financing educational tasks 


\section{Wstęp}

Realizacja wizji edukacji włączającej wysokiej jakości w polskim systemie oświaty powiedzie się, gdy jej główne założenia będą miały mocne oparcie w prawie oświatowym i modelu finansowania jego zadań. W ostatnich latach dynamicznie wzrasta liczba uczniów z niepełnosprawnościami w szkołach ogólnodostępnych. W roku szkolnym 2016/2017 ponad $60 \%$ z nich uczyło się w systemie edukacji włączającej ', a w roku 2018/2019 wskaźnik ten wzrósł do $67 \%^{2}$. Dodatkowo, około $30 \%$ objętych jest pomocą psychologiczno-pedagogiczną i innymi formami wsparcia ${ }^{3}$. Takie dane pozwalają na stwierdzenie, że w wymiarze statystycznym edukacja włączająca jest w Polsce faktem. Ta sytuacja sprawia, że niezbędny jest przejrzysty system finansowania zadań oświatowych, który uwzględnia prymat szkół ogólnodostępnych w kształceniu uczniów ze specjalnymi potrzebami edukacyjnymi. $\mathrm{Na}$ tle diagnozy obowiązujących zasad podziału subwencji oświatowej widoczna jest pilna potrzeba wprowadzenia takich zmian, które zapewnią wszystkim uczniom - nie tylko tym, którzy zostali zakwalifikowani do kształcenia specjalnego - gwarancję odpowiedniego wsparcia. Środki finansowe przewidziane w odrębnych wagach na uczniów z niepełnosprawnością powinny być przyznawane bardziej celowo, a dyrektor szkoły, w największym stopniu odpowiadający za jakość kształcenia w systemie edukacji włączającej, powinien mieć pewien zakres swobody w ich wykorzystaniu. Zaprezentowane kierunki zmian finansowania zadań oświatowych w edukacji włączającej są wynikiem prac Zespołu do spraw opracowania modelu kształcenia uczniów ze specjalnymi potrzebami edukacyjnymi działającego przy Ministrze Edukacji Narodowej ${ }^{4}$, rekomendacji nr 6 Europejskiej Agencji Narodowej. w sprawie sposobu podziału części oświatowej subwencji ogólnej dla jednostek samorządu terytorialnego w roku 2019, bit.ly/2WI9ZpP [dostęp: 3.06.2019]. edukacyjnymi, który został powołany przez Ministra Edukacji Narodowej Zarządzeniem nr 39 z dnia 13 października 2017 r. 
do spraw Specjalnych Potrzeb i Edukacji Włączającej ${ }^{5}$ oraz wielu lat polskich doświadczeń w zarządzaniu oświatą.

\section{Ogólne zasady finansowania zadań oświatowych}

Polski system oświaty funkcjonuje w warunkach decentralizacji administracji publicznej i zdecentralizowanego systemu przekazywania środków publicznych na zadania oświatowe. Fundamentalną zasadą podziału subwencji jest założenie, że „pieniądz idzie za uczniem”. Minister edukacji narodowej, korzystając z danych w Systemie Informacji Oświatowej (SIO) ${ }^{6}$ oraz algorytmu opisanego w rozporządzeniu, ustala jej wysokość na dany rok budżetowy, odrębnie dla każdej z 2807 jednostek samorządu terytorialnego. Istotnym instrumentem dystrybucji środków finansowych jest liczba i rodzaj wag, na podstawie których przekazywane są dodatkowe pieniądze, stanowiące zabezpieczenie finansowe realizacji ponadstandardowych zadań oświatowych. Wartość wag jest asymetrycznie zróżnicowana (od 0,012 do 10). W praktyce podstawowym elementem polityki państwa w finansowaniu zadań oświatowych jest regulacja wskaźników i wag, w tym tych przeznaczonych na uczniów objętych kształceniem specjalnym. Mocną stroną polskiego systemu jest płynność przekazywania środków do budżetów jednostek samorządu terytorialnego, a słabą - dość duża swoboda w ich dystrybucji do planów finansowych szkół, co oznacza, że pieniądze transferowane w subwencji na określone zadania oświatowe nie muszą być w całości przekazane do placówek, które je realizują. Ten problem w największym stopniu ujawnił się w przypadku uczniów objętych kształceniem specjalnym w systemie edukacji włączającej. Ministerstwo Edukacji Narodowej w ramach podziału subwencji oświatowej corocznie przeznacza stosunkowo duże środki na organizację kształcenia specjalnego. W 2019 r. na ten cel wyasygnowano $7,85 \mathrm{mld}$ zł, co stanowi $17,1 \%$ całej kwoty do marca $2019 \mathrm{r}$. 30 września roku poprzedzającego rok budżetowy) obejmujące wszystkie publiczne i niepubliczne przedszkola, szkoły i placówki oświatowe, niezależnie od tego, kto jest ich organem prowadzącym. 
części oświatowej subwencji ogólnej ${ }^{7}$. Raport Najwyższej Izby Kontroli dowodzi, że systematyczny wzrost nakładów na kształcenie specjalne nie idzie w parze z jakością działań na rzecz uczniów. W połowie skontrolowanych szkół i przedszkoli nie zapewniono właściwego wsparcia uczniom z niepełnosprawnościami, a pieniądze przekazane na ich kształcenie zostały wykorzystane na inne zadania oświatowe. Mimo że od 2015 r. wprowadzono wymóg, by jednostki samorządu terytorialnego (JST), a także szkoły i przedszkola planowały oraz ewidencjonowały wydatkowanie środków dodatkowo przekazanych na organizację kształcenia specjalnego w odrębnych, nowo utworzonych rozdziałach klasyfikacji budżetowej, to w $2016 \mathrm{r}$.:

$\rightarrow$ tylko $29 \%$ JST zaplanowało i wykorzystało otrzymane środki,

$\rightarrow 32 \%$ JST zaplanowało, ale nie wykorzystało pieniędzy, które do nich trafiły,

$\rightarrow 39 \%$ JST nie zaplanowało i nie wykorzystało uzyskanych środków finansowych.

\section{Specjalne potrzeby edukacyjne uczniów - aspekt finansowy}

Specjalne potrzeby edukacyjne uczniów wymagają szczególnej organizacji form i metod pracy, co często wiąże się z koniecznością zatrudnienia specjalistów i ponoszenia dodatkowych kosztów. Obecny model podziału subwencji oświatowej zawiera dość stabilny system finansowania uczniów objętych kształceniem specjalnym, ale pokrycie kosztów specjalnych potrzeb edukacyjnych uczniów, którzy nie mają orzeczenia, nie jest uregulowane. W podziale subwencji na 2019 r. uwzględniono cztery wagi dla szkół, na podstawie których na ucznia objętego kształceniem specjalnym przekazywane są dodatkowe transfery finansowe ${ }^{9}$. Na takiego ucznia przekazywany jest zarówno transfer finansowy zgodnie ze standardem A (jak na każdego statystycznego ucznia), jak i dodatkowy, którego wysokość zależy od wartości wagi z niepełnosprawnościami w ogólnodostępnych szkołach i przedszkolach, s. 7, bit.ly/2WN99BG [dostęp: 3.06.2019]. 
przypisanej danemu rodzajowi niepełnosprawności, niedostosowania społecznego lub zagrożenia tym niedostosowaniem. Poniżej wykres pokazujący wartość wag, na podstawie których przekazywane są szkołom środki finansowe na organizowanie kształcenia specjalnego.

Wykres 1. Porównanie wartości transferów finansowych przekazywanych na uczniów objętych odpowiednio kształceniem specjalnym lub zajęciami rewalidacyjno-wychowawczymi w stosunku do wartości standardu A przekazywanego na każdego statystycznego ucznia w 2019 r.

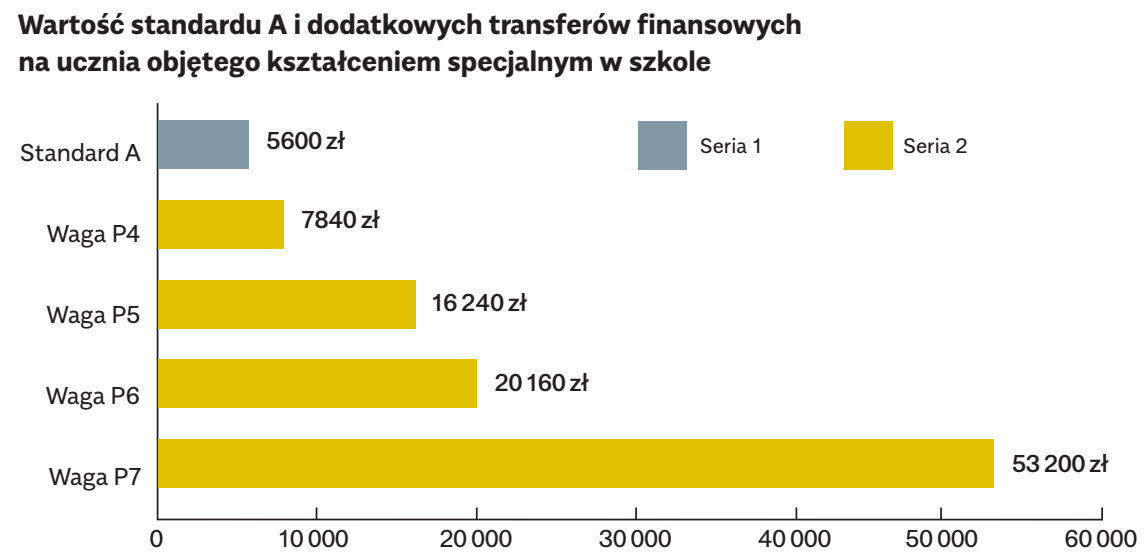

Waga P4 = 1,40 dla uczniów z niepełnosprawnością intelektualną w stopniu lekkim, niedostosowanych społecznie, zagrożonych niedostosowaniem społecznym, na podstawie orzeczeń o potrzebie kształcenia specjalnego.

Waga P5 = 2,90 dla uczniów niewidomych, słabowidzących, z niepełnosprawnością ruchową, w tym z afazją, na podstawie orzeczeń o potrzebie kształcenia specjalnego. Waga P6 = 3,60 dla uczniów niesłyszących, słabosłyszących, z niepełnosprawnością intelektualną w stopniu umiarkowanym lub znacznym, na podstawie orzeczeń o potrzebie kształcenia specjalnego.

Waga P7 = 9,50 dla dzieci i młodzieży z niepełnosprawnością intelektualną w stopniu głębokim, spełniających obowiązek szkolny lub obowiązek nauki przez udział w zajęciach rewalidacyjno-wychowawczych organizowanych w szkołach, ośrodkach i poradniach psychologiczno-pedagogicznych, dla uczniów z niepełnosprawnościami sprzężonymi oraz z autyzmem, w tym z zespołem Aspergera, na podstawie odpowiednio orzeczeń o potrzebie zajęć rewalidacyjno-wychowawczych lub orzeczeń o potrzebie kształcenia specjalnego. 
Jak widać, środki przewidziane na uczniów objętych kształceniem specjalnym są znaczne. Trudno jednak znaleźć merytoryczne uzasadnienie przekazywania na kształcenie specjalne ucznia niewidomego takiej samej kwoty jak na ucznia słabowidzącego (waga P5). Podobne wątpliwości budzi waga P6, na podstawie której duża kwota, konieczna do organizacji kształcenia ucznia niesłyszącego, uwzględnia także ucznia słabosłyszącego, którego edukacja nie generuje tak wysokich kosztów. Wykaz w wadze P7 (niepełnosprawność intelektualna w stopniu głębokim, umiarkowanym i znacznym, autyzm, w tym zespół Aspergera) skutkuje tym, że na kształcenie wysokofunkcjonującego ucznia z zespołem Aspergera przekazywane są takie same kwoty jak na kształcenie osoby z niepełnosprawnością intelektualną w stopniu głębokim. Ta daleko posunięta unifikacja finansowania osób objętych kształceniem specjalnym, dokonywana na podstawie przynależności do szeroko rozumianego rodzaju niepełnosprawności, generuje liczne nieprawidłowości w wykorzystaniu środków przekazywanych do organów prowadzących szkoły. Wcześniej przywołany raport Najwyższej Izby Kontroli ${ }^{10}$ pokazuje, jak w praktyce finansowane są szkoły realizujące kształcenie specjalne w systemie włączenia. „W większości skontrolowanych szkół i przedszkoli na przeszkodzie właściwej realizacji edukacji włączającej stanęły ograniczone zasoby finansowe i kadrowe. Jednakże aż $75 \%$ placówek nie wykorzystywało istniejących możliwości zapewnienia właściwego finansowania kształcenia specjalnego. W latach 2015-2016 nie wydatkowano w szkołach i przedszkolach przysługujących środków w ramach części oświatowej subwencji ogólnej".

Tę niekorzystną diagnozę funkcjonowania edukacji włączającej w obszarze finansowym dopełnia fakt, że obecny model podziału subwencji oświatowej nie przewiduje systemowego wsparcia uczniów, których potrzeby edukacyjne uwarunkowane są innymi przyczynami niż niepełnosprawność. Tymczasem w polskich szkołach ogólnodostępnych systematycznie wzrasta liczba uczniów potrzebujących wsparcia z powodu parcjalnych lub fragmentarycznych zaburzeń rozwojowych, zaniedbań środowiskowych, zagrożenia niedostosowaniem społecznym, odmienności kulturowej i językowej. Takie osoby powinny mieć możliwość skorzystania z pomocy psychologiczno-pedagogicznej, 
ale jej dostarczenie nie jest zadaniem dodatkowo subwencjonowanym, co sprawia, że trudno wyegzekwować skuteczne działania wspierające tych uczniów, zwłaszcza wtedy, gdy konieczne jest zaangażowanie specjalisty. Pierwsze próby uruchomienia ścieżki finansowania pomocy psychologiczno-pedagogicznej w szkołach pojawiły się w podziale subwencji oświatowej na 2019 r. w wagach P46 i P47. Informacje o powodach ich wprowadzenia można znaleźć w uzasadnieniu do projektu rozporządzenia w sprawie sposobu podziału części oświatowej subwencji ogólnej dla jednostek samorządu terytorialnego w roku 2019.

„Projekt przewiduje wprowadzenie dwóch wag na realizację działań z zakresu pomocy psychologiczno-pedagogicznej o wartości 0,025 dla szkół podstawowych i gimnazjum (waga P46) i o wartości 0,012 dla szkół ponadpodstawowych (waga P47). Waga obejmie uczniów z kategorii dzieci i młodzież (wszystkich, a nie tylko objętych pomocą) w szkołach ogólnodostępnych realizujących obowiązek szkolny lub nauki. Zróżnicowanie tych wag wynika z odsetka osób korzystających z pomocy psychologiczno-pedagogicznej w danym typie szkoły: w szkole podstawowej i gimnazjum średnio w kraju 35\% uczniów jest objętych pomocą psychologiczno-pedagogiczną, w szkołach ponadpodstawowych ok. $19 \% " 11$.

\section{Proponowane kierunki zmian w finansowaniu edukacji włączającej}

Zakładane cele edukacji włączającej powinny być osiągane w pierwszej kolejności przez systematyczne wzmacnianie potencjału szkół ogólnodostępnych, ponieważ te placówki muszą wziąć odpowiedzialność za zaspokajanie potrzeb swoich uczniów bez nadmiernego formalizowania udzielanej pomocy. Nowy model finansowania powinien uwzględniać potrzeby uczniów rozpoznane w szkole, a nie tylko te, które są skutkiem diagnozy przeprowadzonej w poradni psychologiczno-pedagogicznej i określone w orzeczeniu lub opinii. Szkoła powinna dysponować podstawowym zasobem specjalistów, którzy ukierunkują jej działania na profilaktykę problemów rozwojowych uczniów i wczesną interwencję. Opisane wcześniej wagi P46 i P47 na organizację pomocy psycholo- 
giczno-pedagogicznej są właściwym kierunkiem zmian i powinny być kontynuowane do czasu, gdy szkoły ogólnodostępne osiągną standardy zatrudnienia specjalistów w szkole włączającej ${ }^{12}$.

Głębokich modyfikacji wymaga także obecny model finansowania kształcenia specjalnego w systemie edukacji włączającej. Uczniowie zakwalifikowani do tej kategorii kształcenia wymagają wysokospecjalistycznego wsparcia nauczycieli, dostosowania przestrzeni szkolnej i stanowiska pracy, a niekiedy również ponadstandardowych warunków opieki medycznej i pomocy asystenta. Każda szkoła, w tym włączająca, powinna zapewnić im całościowe wsparcie, a system finasowania - znaleźć właściwą formułę przekazania środków na ten cel. Mając na uwadze krytyczne raporty dotyczące aktualnego modelu finansowania kształcenia specjalnego należy poszukiwać form bardziej celowej dystrybucji środków, odpowiadającej potrzebom danego ucznia, a nie szeroko rozumianej grupy osób z daną kategorią niepełnosprawności. To założenie skłania do poszukiwania drogi odejścia od finansowania rodzaju niepełnosprawności na rzecz finansowania potrzeb konkretnego ucznia. Ten tok myślenia jest spójny z kierunkiem zmian w orzecznictwie o stopniu niepełnosprawności przyjętym w resorcie rodziny, pracy i polityki społecznej oraz orzecznictwie w systemie oświaty bazującym na ocenie funkcjonowania ucznia. Kierunek ten wynika z dążenia do tzw. jednego orzeczenia, wydawanego przez interdyscyplinarny zespół ${ }^{13}$, który ocenia potrzeby wsparcia w różnych sferach funkcjonowania ucznia, w tym także niezbędne dostosowania w środowisku. $\mathrm{W}$ prezentowanej poniżej koncepcji zmian $\mathrm{w}$ finansowaniu edukacji włączającej nie jest ważny rodzaj niepełnosprawności, ale poziom funkcjonowania ucznia i odpowiadający mu poziom koniecznego wsparcia.

\section{Finansowe dźwignie edukacji włączającej}

W celu realizacji założeń edukacji włączającej wysokiej jakości warto w miejsce czterech wag przypisanych kształceniu specjalnemu w szkołach ogólnodostępnych rozważyć wprowadzenie trzech nowych indo spraw opracowania modelu kształcenia uczniów ze specjalnymi potrzebami edukacyjnymi. 
strumentów finansowych, które łącznie tworzą dwie dźwignie edukacji włączającej.

Pierwsza dźwignia edukacji włączającej to finansowe wsparcie szkół włączających, które gwarantuje im możliwość zatrudnienia specjalistów oraz zapewnienia uczniom różnych form wspomagania w procesie kształcenia, bez konieczności uzyskiwania przez nich opinii i orzeczenia. Potrzeby w obszarze wsparcia uczniów rozpoznawane są w ciągu całego roku szkolnego $w$ toku bieżącej pracy. Zmieniające się w czasie wymagania uczniów powodują, że jego formy i zakres muszą być modyfikowane. Wymaga to zagwarantowania szkołom takiego zasobu organizacyjnego, który umożliwi im realizację wsparcia możliwie najszybciej po rozpoznaniu potrzeby, bez konieczności przechodzenia żmudnych procedur administracyjnych. Najprostszym rozwiązaniem służącym osiągnięciu takiego skutku prawnego w obowiązującym modelu podziału subwencji oświatowej jest dodatkowa waga (instrument finansowy nr 1), odpowiednio wyszacowana dla typu szkoły i ustalonego dla niej standardu zatrudnienia specjalistów. Funkcjonujące od 2019 r. wagi P46 i P47 w podziale subwencji oświatowej są początkiem zmian w tym kierunku.

Druga dźwignia edukacji włączającej dotyczy uczniów o złożonych potrzebach rozwojowych i edukacyjnych, których zaspokojenie wymaga dodatkowych działań szkoły w dłuższym czasie lub przez cały okres kształcenia. W tej grupie znajdą się osoby z niepełnosprawnością, którą należy rozumieć szerzej ${ }^{14}$ niż określają to obecne przepisy prawa oświatowego ${ }^{15}$. Żeby osiągnąć zakładaną przejrzystość i celowość przekazywania środków, wsparcie finansowe ucznia mogłoby się składać z dwóch instrumentów finansowych:

1. dodatkowej wagi w podziale subwencji oświatowej (instrument finansowy nr 2), odpowiadającej poziomowi funkcjonowania ucznia, oszacowanej na podstawie liczby godzin koniecznego ze specjalnymi potrzebami edukacyjnymi przyjęto definicję niepełnosprawności ucznia zgodną z konwencją ONZ o prawach osób niepełnosprawnych, która jest szersza niż obecny katalog niepełnosprawności uprawniających do objęcia ucznia kształceniem specjalnym. 
wsparcia nauczyciela, udzielanego w formie zindywidualizowanej (choć niekoniecznie indywidualnej) pomocy nauczyciela przedmiotu lub terapeuty,

2. dotacji celowej dla szkoły (instrument finansowy nr 3) na sfinansowanie koniecznego dostosowania przestrzeni szkolnej, w tym stanowiska pracy umożliwiającego pełne uczestniczenie ucznia z niepełnosprawnością w zajęciach.

Uprawnienia do korzystania z instrumentu finansowego $\mathrm{nr} 2 \mathrm{nie}$ powinny zależeć od stwierdzenia niepełnosprawności ucznia, nie wszystkie bowiem poważne zakłócenia rozwoju wymagające wsparcia wynikają z niepełnosprawności. Kosztownego wspomagania edukacyjno-specjalistycznego (okresowo lub trwale) mogą wymagać uczniowie z trudnościami w funkcjonowaniu, uwarunkowanymi np. stanem zdrowia czy przebytą traumą. W nowym modelu finansowania edukacji włączającej nie jest ważne, czy zostanie stwierdzony określony rodzaj niepełnosprawności lub czy nastąpi rozpoznanie zaburzenia ${ }^{16}$, ale to, jaki jest poziom funkcjonowania ucznia i odpowiadający mu rodzaj oraz zakres koniecznego wsparcia. Takie podejście umożliwi ograniczenie barier w zakresie pełnego uczestnictwa uczniów w życiu społeczności szkolnej. Wydaje się, że trafnym wskaźnikiem w określeniu potrzeb wynikających z poziomu funkcjonowania ucznia byłaby liczba godzin pracy nauczyciela. Przyjmując takie rozwiązanie, wskaźnik ten byłby podstawą ich sfinansowania. Zakłada się, że pula godzinowa przypisana szkole w tym trybie byłaby przez nią elastycznie rozdzielana, zgodnie z potrzebami ucznia i ustaleniami zespołu wielospecjalistycznego, określającego indywidualny plan edukacyjny i monitorującego jego realizację. Liczby poziomów funkcjonowania ucznia i odpowiadające im liczby godzin wsparcia nauczyciela powinny zostać ustalone w toku działań pilotażowych realizowanych w szkołach i poradniach psychologiczno-pedagogicznych we współpracy z organami prowadzącymi szkoły. Podstawą przyznania dotacji byłyby określone bariery po stronie szkoły, utrudniające funkcjonowanie ucznia.

Zaproponowany kierunek zmian w modelu finansowania zadań oświatowych w edukacji włączającej jest zgodny z rekomendacją 
nr 6 Europejskiej Agencji do spraw Specjalnych Potrzeb i Edukacji Włączającej ${ }^{17}$.

„W ramach polityki edukacyjnej należy opracować mechanizmy finansowania wspierające rozwój wczesnej interwencji i profilaktyki, zamiast polegać na strategiach i podejściach opartych na kompensowaniu trudności w szkołach ogólnodostępnych.

Oznacza to:

$\rightarrow$ wprowadzenie modelu finansowania zapewniającego wszystkim osobom uczącym się, które tego potrzebują, gwarancję wysokiej jakości wsparcia w procesie uczenia się. Model ten powinien zapewnić odejście od stosowania formalnych procedur identyfikacji potrzeb, gdzie głównym kryterium uzyskania dostępu do wsparcia jest «etykietowanie» uczniów. Nowe podejście powinno zagwarantować odpowiednie finansowanie i zasoby umożliwiające wspieranie wszystkich osób uczących się, aby usunąć bariery w uczeniu się i uczestnictwie;

$\rightarrow$ zapewnienie środków finansowych, które mogą być wykorzystywane w elastyczny sposób przez dyrektorów szkół do wdrażania strategii zapobiegających występowaniu problemów i umożliwiających nauczycielom natychmiastową interwencję po ich zidentyfikowaniu;

$\rightarrow$ określenie mechanizmów finansowania skierowanych do osób uczących się, które wymagają bardziej złożonego i długoterminowego wsparcia".

\section{Podsumowanie}

W sytuacji, gdy polski system oświaty przygotowuje się do upowszechnienia edukacji włączającej wysokiej jakości, poszukiwanie nowego modelu finansowania uczniów ze specjalnymi potrzebami edukacyjnymi wydaje się naturalnym obowiązkiem państwa. Zbyt długo tkwimy w rozwiązaniach, których podstawy były tworzone w latach 90. XX w., gdy polski system oświaty był segregacyjny, a model finansowania uczniów z niepełnosprawnością polegał na ustaleniu wskaźnika dla szkół specjalnych, których zasób kadrowy składa się z samych specjalistów z zakresu danej niepełnosprawności. Dynamicznie rozwijające 
się szkoły i klasy integracyjne spowodowały, że do podziału subwencji oświatowej wprowadzono wagi na uczniów z niepełnosprawnością jako podstawę prawną przekazania środków finansowych na ich kształcenie w szkołach ogólnodostępnych w formie integracji lub włączenia. Dzisiaj te rozwiązania już nie wystarczają. Potrzebny jest system finansowania dostosowany do myślenia o szkole, która nie dzieli uczniów na "przeciętnych" i tych „ze specjalnymi potrzebami", ale dąży do urzeczywistnienia modelu kształcenia odpowiadającego na potrzeby każdego ucznia. Instrumentem finansowym wspierającym upowszechnienie edukacji włączającej może być także przeznaczenie części środków zaplanowanych na doskonalenie zawodowe nauczycieli, o których mowa w art. 70a Karty Nauczyciela, na doszkalanie w zakresie kompetencji i kwalifikacji potrzebnych do pracy w zespołach klasowych o zróżnicowanych potrzebach edukacyjnych.

Mam nadzieję, że zaprezentowane kierunki zmian w finansowaniu zadań oświatowych staną się istotnym głosem w dyskusji nad poszukiwaniem rozwiązań, które upowszechnią w Polsce edukację włączającą wysokiej jakości. 